\title{
PROBLEMY WŁASNOŚCI JEZIOR W POLSCE
}

\section{THE PROBLEMS CONCERNING PROPRIETORSHIP OF LAKES IN POLAND}

\section{STRESZCZENIE}

Niniejszy artykuł przedstawia problemy związane z własnością jezior w Polsce. Autorzy wskazują, iż obowiązujące normy prawa klasyfikujące jeziora jako „wodę płynącą" lub „wodę stojącą” są nieprecyzyjne w odniesieniu do przedmiotu swej regulacji. Przepisy Prawa wodnego z 2001 roku wprowadzają nieuzasadniony z hydrologicznego punktu widzenia podział jezior. Powoduje to poważne oraz wieloaspektowe trudności związane ze stosowaniem prawa. Ponadto przepisy te nie znajdują uzasadnienia zarówno od strony ekonomicznej, jak i funkcjonalnej. W celu uzasadnienia powyższych tez autorzy przeprowadzają analizę norm zawartych w Prawie wodnym z 2001 roku i zestawiają otrzymane rezultaty z naturalnymi właściwościami jezior

" WPiA UMK w Toruniu.

** Dr hab., profesor UMK, Kierownik Katedry Hydrologii i Gospodarki Wodnej, Wydział Nauk o Ziemi UMK w Toruniu. 
oraz cieków występujących w ich zlewniach. Ponadto artykuł zawiera istotne dla analizowanej problematyki orzeczenia sądów, przepisy prawa Unii Europejskiej, a także sygnalizuje sporne kwestie występujące podczas klasyfikowania jezior zgodnie z istniejącym prawem.

\section{Słowa kluczowe}

Własność jezior, prawo wodne, hydrologia, woda stojąca.

\section{ABSTRACT}

This article discusses the problems related to proprietorship of lakes in Poland. The authors point out that existing legal provisions, which classify lakes as „flowing water” or „stagnant water” are imprecise to subject of it's regulation. The provisions of Water Law act of 2001 implement unjustified from hydrological point of view division of lakes. This causes significant and multi - faceted difficulties with application of law. Also important is fact, that mentioned provisions can not be justified because of it's economy or functionality. In order to prove all above thesis, the authors analyze the provisions of Water Law act of 2001 and compare obtained results with the natural properties of lakes and streams occurring in lake's catchments. This article covers important for presented topic judgments, European Union law's provisions and also indicates numerous issues which take place during the classifying of lakes in accordance to law in force.

Keywords

Proprietorship of lakes, Water Law, hydrology, stagnant water.

\section{WSTĘP}

Woda jest jednym z najważniejszych elementów każdego ekosystemu. Umożliwia byt i rozwój człowieka oraz wszelkich innych organizmów, a jednocześnie wywiera istotny wpływ na abiotyczne elementy przyrody. Ze względu na swoje wyjątkowe znaczenie i uniwersalne zastosowanie w praktycznie każdej dziedzinie życia oraz specyfikę przejawiającą się m.in. 
w odnawialności jej zasobów czy występowaniu szeregu powiązanych ze sobą środowisk egzystencji różnorakich organizmów, jest przedmiotem zainteresowania praktycznie wszystkich podmiotów.

Z uwagi na powyższe, a także $\mathrm{w}$ celu zapewnienia właściwej gospodarki wodnej, prawo własności wód musi różnić się od powszechnej, cywilistycznej konstrukcji prawa własności. Tworzy się więc odrębną, sui iuris konstrukcję normatywną ${ }^{1}$, która wprowadzając pewne konieczne, w obszarze uprawnień właściciela rozwiązania, ma za zadanie zapewnić możliwie najwłaściwsze wykonywanie prawa własności wód. Ryszard. Paczuski wskazuje, że klasyfikując wodę w kategoriach prawa cywilnego jako przedmiot samoistny, nie można uznać jej za rzecz, a tym samym problematyka własności wód, zwłaszcza płynących, nie jest przedmiotem regulacji kodeksu cywilnego ${ }^{2}$. Jeżeli zaś, w określonych przypadkach, woda ma samodzielność w sensie gospodarczego wykorzystania, to mimo wszystko nie uzyskuje ona charakteru rzeczy w rozumieniu art. 45 kodeksu cywilnego $^{3}$. W tej kwestii - ogólnie - panuje zgoda w literaturze przedmiotu.

Niezależnie od problematyki własności woda jest w sposób nierozerwalny związana ze środowiskiem i z różnymi obszarami działalności człowieka. $Z$ tego powodu jest ona intensywnie wykorzystywana do różnorodnych celów, m.in. do zaopatrywania ludności w wodę, dostarczania wody na potrzeby przemysłu, rolnictwa i transportu, wykorzystania w turystyce i rekreacji, uprawiania sportu, ochrony przed suszą lub pożarami oraz umożliwia istnienie i funkcjonowanie naturalnego środowiska (ekosystemu) dla wszystkich organizmów. W polskim porządku normatywnym podstawowym aktem prawnym regulującym zagadnienia związane z problematyką wód, w tym ich własno-

1 B. Wierzbowski, B. Rakoczy, Prawo ochrony środowiska. Zagadnienia podstawowe, Warszawa 2012, s. 194.

2 R. Paczuski, Potrzeby i problemy reformy polskiego prawa wodnego, [w:] M. Bączyk (red.), Księga pamiątkowa ku czci Profesora Leopolda Steckiego, Toruń 1997, s. 653.

3 S. Rudnicki, O własności wód, „Nowe Prawo” 1982, nr 7-8, s. 85. 
ścią, jest ustawa z dnia 18 lipca 2001 r. Prawo wodne ${ }^{4}$, a zagadnienia dotyczące ich ochrony znajdują się w ustawie $\mathrm{z}$ dnia 27 kwietnia 2001 roku Prawo ochrony środowiska5 . W powyższych źródłach prawa woda dzielona jest na „stojącą” i „płynącą". Jednakże kryteria tego podziału są inne niż obowiązujące w hydrologii, czyli - najogólniej - nauce o wodzie. Powoduje to szereg konfliktów związanych z klasyfikacją obiektów hydrologicznych, w tym przede wszystkim jezior.

\section{WŁASNOŚĆ JEZIOR W POLSCE}

Zgodnie z art. 1 ust. 1 ustawy z dnia 7 września 2007 r. o ujawnieniu w księgach wieczystych prawa własności nieruchomości Skarbu Państwa oraz jednostek samorządu terytorialnego ${ }^{6}$, starostowie są zobowiązani do przekazania wojewodom, marszałkom województw, wójtom, burmistrzom i prezydentom miast wykazu nieruchomości, które na mocy odrębnych przepisów przeszły na własność Skarbu Państwa, stanowiąc jego własność albo własność jednostek samorządu terytorialnego. Przytoczony przepis, mając za zadanie uporządkowanie przysługujących Skarbowi Państwa oraz jednostkom samorządu terytorialnego praw własności nieruchomości, wymusił podjęcie odpowiednich działań przez zobowiązane do tego organy administracyjne, dając asumpt do ostatecznego rozwiązania wszelkich, niekiedy zawiłych kwestii w tym przedmiocie. Szczególnym przypadkiem komplikacji mogących powstać w trakcie egzekwowania wskazanych przepisów jest problematyka własności jezior, gdyż - ze względów klasyfikacyjnych wskazanych w prawie wodnym - nie są kategorią jednolitą. Przedmiotowy akt normatywny w art. 5 ust. 3 pkt 1 lit. b dzieli śródlądowe wody powierzchniowe na wody płynące, które znajdują się w jeziorach o ciągłym bądź okresowym naturalnym dopływie

4 Tj. Dz.U. z 2012 r., poz. 145 ze zm.

5 Tj. Dz.U. z 2013 r., poz. 1232 ze zm.

6 Dz.U. z 2007 r. Nr 191, poz. 1365 ze zm. 
lub odpływie wód powierzchniowych oraz, w art. 5 ust. 3 pkt 2 na wody stojące, znajdujące się $\mathrm{w}$ jeziorach niezwiązanych bezpośrednio, w sposób naturalny z powierzchniowymi wodami płynącymi. Art. 10 ust. 1 omawianej ustawy wskazuje, iż do podmiotów, którym może przysługiwać prawo własności wód należą Skarb Państwa oraz inne osoby prawne bądź fizyczne, jednakże, zgodnie z art. 10 ust. 3, płynące wody publiczne nie podlegają obrotowi cywilnoprawnemu. Wobec powyższego należy uznać, że tylko jeziora sklasyfikowane jako „woda stojąca” mogą być przedmiotem własności osób fizycznych.

Dalsze podjęte $\mathrm{w}$ niniejszej pracy rozważania będą miały za zadanie wskazać, że chociaż zastosowany w Prawie wodnym podział jezior spełnia formalne warunki poprawności dychotomicznego podziału logicznego (przy uwzględnieniu uwag poczynionych w dalszej części pracy), a sam akt normatywny, w omawianej kwestii, nie zawiera nieścisłości czy niespójności, to wprowadzone przezeń kryterium podziału jezior jest wyjątkowo trudne do zastosowania $\mathrm{w}$ praktyce. Innymi słowy, teoretyczna poprawność analizowanych norm prowadzi do wielu problemów empirycznych związanych z ustaleniem, zgodnie z przepisami prawa, typu konkretnego jeziora, a tym samym ewentualną możliwością jego nabycia bądź utrzymania (jeżeli zgodnie z księgami wieczystymi prawo własności przysługuje osobie prywatnej) przez odrębny od Skarbu Państwa podmiot.

\section{ZAGADNIENIE POJĘĆ WODY PŁYNĄCEJ I WODY STOJĄCEJ W KONTEKŚCIE WŁASNOŚCI JEZIOR}

Zgodnie z obowiązującym stanem prawnym, aby jezioro mogło stać się własnością prywatną, musi być sklasyfikowane jako „woda stojąca”, czyli nie może być ono związane bezpośrednio, w sposób naturalny, z powierzchniowymi wodami płynącymi (art. 5 ust. 3 pkt 2 Prawa wodnego). Przedmiotowa norma nie jest precyzyjna $\mathrm{z}$ dwóch powodów.

Pierwszy dotyczy wykładni pojęcia „bezpośrednio”. Dlaczego w ogóle ustawodawca zdecydował się na zawarcie takie- 
go wymogu? Przede wszystkim wydaje się, że w analizowanym przypadku chodzi o potoczne rozumienie terminu „bezpośrednio", definiowane jako związanie wprost z powierzchniowymi wodami płynącymi. Czy zatem mogą pojawić się sytuacje, w których jezioro A połączone jest w sposób naturalny (choć nie bezpośrednio) z jeziorem $B$ (albo ogólnie ze śródlądową powierzchniową wodą płynącą), a to z kolei (B), jest związane bezpośrednio z powierzchniowymi wodami płynącymi? Wobec powyższego wydaje się, że teoretycznie, można konstruować tezy, zgodnie z którymi połączenie ma charakter pośredni, zwłaszcza jeżeli stan faktyczny jest bardzo skomplikowany np. gdy występuje więcej różnego rodzaju elementów hydrologicznych (np. kanały, źródła, sztuczne zbiorniki wodne usytuowane na wodach płynących). Taka konstrukcja przedstawionej normy jest dwuznaczna, ponieważ może doprowadzić do zakwalifikowania podobnych względem siebie jezior do różnych typów. Przykładem jest sytuacja, w której jeziora A i B mają tożsame cechy hydrologiczne i hydrogeologiczne. Jednakże jezioro A jest związane bezpośrednio z powierzchniowymi wodami płynącymi, z kolei jezioro B pośrednio. W rezultacie pomimo podobieństwa jezior A i B mogą one należeć do różnych rodzajów wód. Przyjmując nawet argument, iż taki podział wód zdeterminowany jest kryterium funkcjonalnym (a także fizycznym), to nie znajduje ono odzwierciedlenia we wskazanych stanach faktycznych i prowadzi do sztucznej, często nieuzasadnionej jakimikolwiek względami klasyfikacji jezior. Podsumowując poczynione wyżej rozważania, podkreślić trzeba, iż wprowadzenie w Prawie wodnym określenia ,jezioro niezwiązane bezpośrednio, w sposób naturalny, z powierzchniowymi wodami płynącymi" powoduje dodatkowe komplikacje podczas ustalania typu jezior. Skoro zakłada się istnienie bezpośredniego związania jeziora z powierzchniowymi wodami płynącymi, to należy rozumieć, że istnieją także sytuacje, w których jeziora mogą być związane z powierzchniowymi wodami płynącymi w sposób pośredni. Tymczasem nie ma takich możliwości, aby jezioro było związane z tymi wodami w sposób bezpośredni lub pośredni. Każde jezioro albo jest związane z powierzchniowymi wodami 3/2013 płynącymi, albo nie jest $\mathrm{z}$ nimi związane. Analizowany przepis 
dodatkowo komplikuje klasyfikowanie jezior i utrudnia zarówno sądom, jak i organom administracyjnym podjęcie właściwej oceny co do typu jeziora.

W tym miejscu należy wskazać jeszcze, że wykładnia art. 5 ust. 3 pkt 2 Prawa wodnego może budzić wątpliwości, ponieważ nie wiadomo, czy chodzi o jeziora same w sobie oraz odrębnie o naturalne zbiorniki wodne niezwiązane bezpośrednio, w sposób naturalny, z powierzchniowymi wodami płynącymi czy też warunki niezwiązania bezpośredniego i naturalnego dotyczą jezior i innych naturalnych zbiorników wodnych? Jeżeli przyjąć, iż są to odrębne rodzaje wód, to poczynione wyżej rozważania nie mają racji bytu. Powstałe nieścisłości można rozwiązać odwołując się do art. 5 ust. 3 pkt 1 lit. B Prawa wodnego. Zgodnie z nim do śródlądowych powierzchniowych wód płynących zalicza się wody znajdujące się w jeziorach oraz innych naturalnych zbiornikach wodnych o ciągłym bądź okresowym naturalnym dopływie lub odpływie wód powierzchniowych. Wobec powyższego należy stwierdzić, że kryterium ciągłych bądź okresowych naturalnych dopływów lub odpływów wód powierzchniowych dotyczy zarówno jezior, jak i innych naturalnych zbiorników wodnych. Zatem, zdaniem autorów, należy przyjąć również, że warunek bezpośredniego związania, w sposób naturalny, z powierzchniowymi wodami płynącymi dotyczy także jezior uznanych za „wodę stojącą” (art. 5 ust. 3 pkt 2 Prawa wodnego). Wykładnia, zgodnie z którą analizowane przepisy dotyczą jezior w ogóle, prowadzi do wykluczających się wzajemnie rezultatów. Nie znajduje jednocześnie uzasadnienia stosowania różnej wykładni dla identycznie skonstruowanych przepisów zawartych w obrębie jednego artykułu (art. 5 Prawa wodnego).

Drugim powodem utrudniającym właściwe ustalenie tupu jezior jest odmienne rozumienie w Prawie wodnym wody stojącej i wody płynącej w porównaniu do klasyfikacji przyjętej od wielu lat w hydrologii. We wszystkich podręcznikach oraz opracowaniach naukowych jeziora zaliczane są do wód stojących $^{7}$. Jeziorami określa się obiekty o powierzchni większej od

7 Zob. E. Bajkiewicz-Grabowska, Z. Mikulski, Hydrologia ogólna, Warszawa 2008 . 
1 ha, które wyróżniają się zupełnie odmiennymi cechami fizyczno-chemicznymi i morfometrycznymi od cieków, czyli od wód płynących. Z tego też względu brak jest jakiegokolwiek uzasadnienia, aby część jezior klasyfikować jako wody stojące, a część jako wody płynące. Istnieje więc zasadnicza rozbieżność między udokumentowanym szeroko $\mathrm{w}$ literaturze naukowym rozumieniu wód stojących a normami ustawowymi. Ponadto przedmiotowe normy kilkukrotnie ulegały zmianom $\mathrm{w}$ okresie powojennym (z powodu nieścisłych sformułowań), co dodatkowo komplikuje problem ustalania właściwego typu jezior. Zasygnalizowaną sytuację, w sposób syntetyczny, przedstawiono w tabeli 1.

Tabela 1. Najważniejsze akty prawne regulujące klasyfikację jezior i kwestie ich własności ${ }^{8}$

\begin{tabular}{|c|l|l|}
\hline Rok & \multicolumn{1}{|c|}{ Podstawa prawna } & \multicolumn{1}{c|}{ Sposób regulacji własności jezior } \\
\hline 1922 & $\begin{array}{l}\text { Ustawa wodna z dnia } \\
\text { 19 września } 1922 \text { r.; } \\
\text { Dz.U. z } 1922 \text { r. Nr 102, } \\
\text { poz. 336. }\end{array}$ & $\begin{array}{l}\text { Dla ustalenia własności jeziora nie miało } \\
\text { znaczenia, czy jest ono uważane za wodę } \\
\text { stojącą, czy płynącą. Każdy jego rodzaj } \\
\text { mógł być przedmiotem własności prywat- } \\
\text { nej. }\end{array}$ \\
\hline $\begin{array}{l}\text { Ustawa z dnia } 30 \text { maja } \\
\text { 1962 r. Prawo wodne; } \\
\text { Dz.U. z } 1962 \text { r. Nr 34, } \\
\text { poz. 158. }\end{array}$ & $\begin{array}{l}\text { Mocą tej ustawy zdefiniowano i przejęto } \\
\text { na rzecz Skarbu Państwa jeziora prze- } \\
\text { pływowe (woda płynąca), ale tylko gdy } \\
\text { wpływają lub do nich uchodzą cieki stałe. }\end{array}$ \\
\hline $\begin{array}{l}\text { Ustawa z dnia 24 } \\
\text { października 1974 r. } \\
\text { Prawo wodne; Dz.U. } \\
\text { z 1974 r. Nr 38, poz } \\
\text { 230. }\end{array}$ & $\begin{array}{l}\text { Do zakwalifikowania jezior jako prze- } \\
\text { pływowych, ustawa ta jako wymóg ujęła } \\
\text { ogólnie cieki wypływające lub uchodzące } \\
\text { do nich. Należy zatem przyjąć, że rozsze- } \\
\text { rzyła własność Skarbu Państwa o te jeziora } \\
\text { przepływowe, które wcześniej nie stały się } \\
\text { jego własnością z powodu występowania } \\
\text { cieków okresowych. }\end{array}$ \\
\hline 2001 & $\begin{array}{l}\text { Ustawa z dnia } 18 \text { lipca } \\
\text { 2001 r. Prawo wodne; } \\
\text { Dz.U. 2001 nr 115 } \\
\text { poz. 1229 ze zm. }\end{array}$ & $\begin{array}{l}\text { Klasyfikacja jezior (woda stająca lub pły- } \\
\text { nąca) w zależności występowania cieków } \\
\text { (naturalnych lub sztucznych) dopływają- } \\
\text { cych lub odpływających. }\end{array}$ \\
\hline
\end{tabular}

8 K. Kubiak-Wójcicka, M. Marszelewski, Definitions and evolutions of the terms "flowing and stagnant waters" in the context of the proprietorship of the lakes in Poland, "Limnological Review" 2012, nr 4, s. 190. 
Z informacji zestawionych w tabeli 1 wynika, że wymagania związane $\mathrm{z}$ klasyfikowaniem jezior nie tylko ulegały zmianom, ale także od momentu wejścia w życie Prawa wodnego z 1962 roku obarczone są różnorodnymi nieścisłościami. Co ciekawe, jedyny niebudzący wątpliwości i zgodny z hydrologiczną typologią jezior jest podział wprowadzony przez ustawę wodną z 1922 roku. O ile chęć możliwie najdalej idącego upaństwowienia jezior na mocy ustaw z 1962 roku i 1974 roku była uzasadniana panującym ówcześnie w Polsce ustrojem socjalistycznym, o tyle obecne, bezkrytyczne posługiwanie się tymi przepisami może dziwić, zwłaszcza, że najważniejsze teoretyczne usprawiedliwienie ich obowiązywania straciło rację bytu. Trudno jest także odwoływać się do klasycznego prawa rzymskiego, które zgodnie z paremią flumina omnia sunt publica wykluczyło własność prywatną śródlądowych wód płynących. Chociaż zasady i rozwiązania przez nie wprowadzone odcisnęły znaczące piętno na późniejszym (również dzisiejszym) ustawodawstwie niemal wszystkich europejskich krajów, to wobec coraz bardziej skomplikowanych stosunków wodnych oraz nieporównywalnie większego zasobu wiedzy na temat ustroju hydrologicznego śródlądowych wód powierzchniowych, nie mogą być one zawsze przyjmowane bezrefleksyjnie.

Po 1989 roku podjęto działania mające na celu dostosowanie własności zasobów wodnych do zmian ustrojowych. Za przykład może posłużyć projekt ustawy Prawo wodne z dnia 19 kwietnia 1995 roku, który został zakwestionowany m.in. przez R. Paczuskiego, właśnie z powodu braku wprowadzenia prostego podziału własności wód na publiczne i prywatne . Autor wskazuje ponadto, iż „propagowanie [...] zmian w ustawodawstwie, nie będących wynikiem pogłębionych studiów i badań, którym towarzyszy tylko pewne tło emocjonalne, o określonym koniunkturalnie zabarwieniu politycznym [...] prowadzi do wadliwych rozwiązań legislacyjnych"10. Pomimo dostrzeżenia omawianego problemu, do dnia dzisiejszego, spor-

9 R. Paczuski, Opinia do projektu ustawy Prawo Wodne. Ekspertyza nr 52, Kancelaria Sejmu, Biuro Studiów i ekspertyz, Warszawa 1995.

10 R. Paczuski, Potrzeby..., s. 647. 
na kwestia nie została rozwiązana. Warto wskazać również, że na mocy art. 131 Prawa wodnego z 1974 roku naczelnik powiatu mógł przyznać osobom, które były właścicielami wód płynących przejętych z dniem 12 grudnia 1962 roku na własność Państwa i korzystały z nich do celów rybackich prawo dożywotniego, nieodpłatnego korzystania z tych wód do celów rybackich. W sytuacji zaś, gdy stan zdrowia wspomnianych osób nie pozwalał im na korzystanie z przejętych przez państwo wód, albo gdy wody te zostały zagospodarowane przez jednostki gospodarki uspołecznionej przed dniem wejścia w życie ustawy, wojewoda mógł przyznać z tego tytułu odszkodowanie na zasadach i w trybie ustalonym przez Radę Ministrów. Wnioski we wskazanym wyżej przedmiocie musiały być jednak złożone do końca 1977 roku.

W literaturze przedmiotu zasygnalizowano także nieścisłość wynikającą z art. 5 ust. 3 pkt 1 lit. b obowiązującego Prawa wodnego. Zgodnie z nim do płynących śródlądowych wód powierzchniowych zalicza się wody, które znajdują się w jeziorach o ciągłym bądź okresowym naturalnym dopływie lub odpływie wód powierzchniowych. Jan Szachułowicz zaznacza, że „W poprzednim stanie prawnym zapis o wodach płynących był bardziej ścisły, gdyż stanowił o ciekach stałych i okresowych, a obecnie mogą powstać wątpliwości, czy do cieków naturalnych można zaliczyć cieki okresowe, zwłaszcza wtedy, gdy są one krótkotrwałe i woda w nich nie zależy od źródeł, z których cieki biorą początek, lecz od opadów"11.

Ramowa Dyrektywa Wodna ${ }^{12} \mathrm{w}$ art. 2 pkt 5 definiuje jezioro jako część wód śródlądowych powierzchniowych stojących. Jest to zgodna $\mathrm{z}$ hydrologicznym kryterium podziału typologia jezior. Jednakże, z uwagi na fakt, iż wskazany przepis zawarty jest w dyrektywie, to kraje Unii Europejskiej nie muszą do-

11 J. Szachułowicz, Prawo wodne. Komentarz, Warszawa 2010, s. 40.

12 Dyrektywa 2000/60/WE Parlamentu Europejskiego i Rady z dnia 23 października 2000 r. ustanawiająca ramy wspólnotowego działania w dziedzinie polityki wodnej, tzw. Ramowa Dyrektywa Wodna, Dz.Urz. WE L 327 z 22.12.2000, s. 1; Dz.Urz. UE Polskie wydanie specjalne, rozdz. 15, t. 5, str. 275 ze zm. 
konywać jego implementacji. Teoretycznie państwowe normy prawne powinny być interpretowane $\mathrm{w}$ ich świetle. Wydaje się, że w orzecznictwie Europejskiego Trybunału Sprawiedliwości można wskazać tendencję, zgodnie z którą jeżeli przepisy dyrektywy są bezwarunkowe i precyzyjne, to obywatele mogą się na nie powoływać. Mimo powyższego, poruszona kwestia, z uwagi na swą dużą zawiłość, jest przedmiotem odrębnej debaty.

W świetle obowiązującego Prawa wodnego nie można starać się o jakąkolwiek rekompensatę za „przejęcie” na rzecz Skarbu Państwa (jednostki samorządu terytorialnego) jeziora „wody płynącej” - gdyż z istniejących przepisów wynika, że tylko jemu może przysługiwać taka własność. Osobie prywatnej (widniejąca w księdze wieczystej jako właściciel), która nabyła lub odziedziczyła jezioro zgodnie z prawem, gdy było ono uznane za „wodę stojącą", po zmianie (często wątpliwej z hydrologicznego punktu widzenia) klasyfikacji na „wodę płynącą” nie przysługują jakiekolwiek prawa (z wyjątkiem roszczenia wobec podmiotu, który sprzedał jezioro, co często z uwagi choćby na upływ wielu lat jest bardzo trudne, kłopotliwe i nie zawsze możliwe do wyegzekwowania), nawet jeżeli nabyła ona jezioro w dobrej wierze, w sposób zgodny z prawem oraz zachowała wymaganą, w takich sytuacjach, staranność, a w całej procedurze pośredniczył notariusz. Często zmiana klasyfikacji jeziora odbywa się wiele lat po zaistnieniu wskazanych okoliczności i poza widniejącym w księdze wieczystej właścicielem.

Z uwagi na fakt, iż obowiązujące Prawo wodne operuje niewłaściwym kryterium podziału w odniesieniu do przedmiotu swojej regulacji, w zestawieniu z innymi, funkcjonującymi $\mathrm{w}$ porządku normatywnym przepisami, powstaje wiele podobnych do wskazanych wyżej, niepożądanych sytuacji. Osłabiają one pewność obywateli co do prawa oraz mocno obniżają jego jakość. 


\section{PRZYKEADY SPORÓW O WŁASNOŚĆ JEZIOR}

Zgodnie z uchwałą Sądu Najwyższego z dnia 8 listopada 1971 roku $^{13}$, która uzyskała status zasady prawnej, wody i grunty, które stosownie do ustawy wodnej z dnia 19 września 1922 roku stanowiły własność prywatną, a według Prawa wodnego z dnia 30 maja 1962 roku zostały zaliczone do mienia stanowiącego własność Państwa, stały się własnością Państwa z dniem wejścia w życie prawa wodnego. Ponadto stwierdzono, iż sprawy o własność wód i związanych z nimi gruntów podlegają rozpoznaniu w postępowaniu sądowym.

Kwestię przejścia na własność Skarbu Państwa (jednostek samorządu terytorialnego) gruntów i wód w jeziorach płynących musiał doprecyzować również wyrok Sądu Najwyższego z dnia 29 października 1981 roku $^{14}$, który wobec ówcześnie obowiązujących, niejasnych przepisów, stwierdzał, że w sytuacji, gdy jeziora i zajęte pod nie grunty nie są zasilane ciekami wodnymi o przepływach stałych, tylko ciekami o przepływach okresowych, to nie mogą być one przejęte na mocy Prawa wodnego z 1962 roku na rzecz państwa.

Innym przykładem skomplikowanej sytuacji, związanej z własnością jeziora jest wyrok Naczelnego Sądu Administracyjnego z dnia 28 maja 2003 roku ${ }^{15}$, w którym Sąd uchylił zaskarżoną decyzję wojewody w przedmiocie gleboznawczej klasyfikacji gruntów. Z uzasadnienia wynika, że działka, którą stanowi jezioro, najpierw była objęta prawem wieczystego użytkowania, a następnie odpowiednią decyzją prawo to zostało przekształcone w prawo własności. Po pewnym czasie zaczęły się działania burmistrza, w przedmiocie zmiany statusu działki, która została nabyta jako teren pod wodą stojącą. Postawiono jasno pyta-

13 Sygn. akt III CZP 28/71, „Orzecznictwo Sądu Najwyższego. Izba Cywilna " 1972, z. 3, poz. 43.

14 Sygn. akt I CR 208/81, „Orzecznictwo Sądu Najwyższego. Izba Cywilna" 1982, z. 4, poz. 59.

15 Sygn. akt II SA 3313/02, [online], dostęp: 15.09.2013, < http://www. orzeczenia-nsa.pl/wyrok/ii-sa-3313-02,ochrona_srodowiska_i_przyrody,3606d54.html>. 
nie, czy to jezioro jest wodą płynącą, czy stojącą? Ostatecznie stwierdzono, że jest wodą płynącą, jednak nie było to w pełni przekonujące. Jeden z zarzutów uzasadniających zmianę klasyfikacji bazował na stwierdzeniach, zgodnie z którymi przy ocenie charakteru wód jeziora nie wykorzystano jako dowodów szeregu opinii załączonych do akt sprawy i nie zapewniono wszystkim stronom czynnego udziału w postępowaniu administracyjnym. Meritum sprawy dotyczyło problematyki legalności decyzji i kompetencji administracyjnych, nie był to spór o własność. Niemniej ukazuje komplikacje powstałe na etapie postępowania administracyjnego w przedmiocie własności jezior.

Wyrok Naczelnego Sądu Administracyjnego w Warszawie z dnia 12 stycznia 2010 roku $^{16}$ również dotyczy przedstawianej problematyki. Sąd po rozpatrzeniu skargi kasacyjnej od wyroku Wojewódzkiego Sądu Administracyjnego na decyzję Wojewódzkiego Inspektora Nadzoru Geodezyjnego i Kartograficznego w Olsztynie w przedmiocie zmiany oznaczenia użytku gruntowego jeziora oddalił skargę kasacyjną. W uzasadnieniu do wskazanego orzeczenia znajduje się opis skomplikowanego stanu faktycznego wraz z podjętymi działaniami, których celem było ustalenie typu spornego jeziora. Wszystkie przedstawione tam okoliczności potwierdzają tezy wysuwane przez autorów. Naczelny Sąd Administracyjny, rozstrzygając sprawę, nie udzielił odpowiedzi w przedmiocie typu spornego jeziora, ponieważ stwierdził, że skarga nie jest zasadna, gdyż przysługujące skarżącemu prawo rybackiego użytkowania spornego jeziora nie uprawnia go do wystąpienia $\mathrm{z}$ wnioskiem o zmianę jego klasyfikacji.

Powołane orzeczenia sądów i stany faktyczne mają na celu praktyczne ukazanie całego, skomplikowanego problemu własności jezior, który często nie jest tylko klasycznym sporem o własność wód podlegającym właściwości sądów powszechnych, ale także jest przedmiotem postępowania administracyjnego.

16 Sygn. akt I OSK 463/09, LEX nr 595391. 


\section{PRZYKŁADY KOMPLIKACJI BĘDĄCYCH REZULTATEM NIEŚCISŁOŚCI W PRAWIE WODNYM}

W ostatnich latach wyraźnie wzrosła liczba postępowań sądowych w sprawach związanych z własnością jezior. Dotyczą one najczęściej jezior nabytych zgodnie z prawem przez osoby prywatne w latach wcześniejszych. Osoby te legitymują się aktami notarialnymi i są wpisane są jako właściciele jezior w księgach wieczystych. Zdarzają się także sytuacje, w których jezioro będące własnością prywatną stanowiło część masy spadkowej, a w postępowaniu o jego podział brał udział sąd, który uznawał jezioro za własność prywatną spadkobierców.

Postępowania sądowe w sprawach dotyczących przejęcia przez Skarb Państwa (jednostkę samorządu terytorialnego) tzw. jezior prywatnych wywołują dużo emocji ze względu na błędne z hydrologicznego punktu widzenia zapisy Prawa wodnego. Implikuje to konieczność powoływania biegłych zarówno przez sądy, jak i strony postępowania. Często zdarza się, że ekspertyza biegłego opracowana zostaje wyłącznie na podstawie dokumentów kartograficznych i urzędowych, bez badań przeprowadzonych w terenie. Mając na uwadze fakt, że problem dotyczy najczęściej jezior o niewielkich powierzchniach (od kilku do kilkudziesięciu ha), opracowanie ekspertyzy tylko na podstawie wspomnianych materiałów jest najczęściej obarczone błędami, gdyż często zawierają one szereg nieścisłości merytorycznych (np. przebieg działów wodnych czy rodzaje cieków). Biegli często powołują się na Mapę Podziału Hydrograficznego Polski ${ }^{17}$, której skala nie pozwala na precyzyjne ustalenie rodzaju cieku (zwłaszcza małego) dopływającego lub odpływającego z jeziora będącego przedmiotem sporu. Jedynym rozwiązaniem w większości przypadków jest przeprowadzenie ekspertyzy na podstawie wyników badań terenowych. Tego rodzaju badania są kosztowne, gdyż powinny obejmować zarówno elementy hydrologiczne, jak i geomorfologiczne, a często także hydrobiologiczne. Ze względu na wysoką kosztochłonność wskazanych

17 Mapa Podziału Hydrograficznego Polski, Warszawa 2005. 
badań nie zawsze mogą one być przeprowadzone, szczególnie w sytuacjach, gdy jedna ze stron postępowania nie dysponuje wystarczającymi środkami. Należy także podkreślić, że wielu właścicieli jezior nie stać na zlecenie ekspertyzy wykwalifikowanym specjalistom, tym bardziej, że koszty zebrania dowodów w celu utrzymania własności (w księgach wieczystych widnieje jako właściciel osoba fizyczna - strona postępowania) przewyższają wartość przedmiotu sporu - czyli jeziora.

Nie można również pominąć istotnego faktu dodatkowo utrudniającego ustalenie typu jeziora zgodnie z obowiązującym Prawem wodnym. Jest on związany ze znacznymi przekształceniami stosunków wodnych w zlewniach jezior. Przekształcenia te następowały począwszy od średniowiecza, a nasiliły się szczególnie w XIX i XX w. związku z błyskawicznym rozprzestrzenianiem się prac melioracyjnych. W wyniku przeprowadzenia tych prac nastąpił wzrost ilości cieków płynących sztucznymi rowami dopływającymi lub odpływającymi z jezior. Wybudowane zostały w celu odprowadzania nadmiaru wody z obszarów podmokłych lub w celu zwiększenia powierzchni danej zlewni i tym samym jej zasobów wodnych. W wielu przypadkach cieki tego rodzaju stanowią aktualnie dopływ lub odpływ z jeziora i są różnie kwalifikowane (jako sztuczne bądź naturalne). Ustalenie rzeczywistego typu danego cieku jest często trudne bez przeprowadzenia badań specjalistycznych. Wskazane trudności wynikać mogą z braku konserwacji koryt cieków sztucznych i silnym ich przekształceniem pod wpływem czynników naturalnych (np. erozji, denudacji, akumulacji, zarastania). Ustalenie rzeczywistego typu tego rodzaju cieku (co z kolei decyduje o typie jeziora według Prawa wodnego) wyłącznie na podstawie materiałów kartograficznych jest niemożliwe.

Postępowania sądowe dotyczące własności jezior są długotrwałe i powodują występowanie szeregu komplikacji, a nawet szkód. Wymagają udziału wielu osób i utrudniają właścicielom korzystanie z jezior. Wszelkie ich inicjatywy i działalność dotycząca jezior są blokowane z uwagi na fakt zawisłości sporu (np. problemy związane choćby z rekreacyjnym połowem ryb czy budową pomostu). Autorom niniejszego opracowania znany jest przypadek, kiedy tuż przed wizją sądu w terenie usu- 
nięto roślinność charakterystyczną dla wód stojących (w tym gatunki chronione) w celu odebrania jednej ze stron argumentu przemawiającego za brakiem przepływu wody w kanale.

W tym miejscu warto również odnieść się do rozbieżności znajdujących się w dokumentacjach melioracyjnych, w których często sztuczne cieki wodne określane są jako „kanały” lub „rowy”. Tymczasem podczas postępowań sądowych, w zależności od okoliczności wykazuje się, iż określenie cieku w dokumentacji jako „kanał” lub „rów” nie oznacza jego sztucznego pochodzenia. Prowadzi to do skrajnych nieścisłości i konieczności przeprowadzania kolejnych dowodów. W hydrologii określenie „kanał” lub „rów” oznacza jednoznacznie ciek pochodzenia antropogenicznego (sztucznego).

Skrajnym przypadkiem nieścisłości wynikającym z obowiązującego Prawa wodnego jest zakwalifikowanie południowej części jeziora Radodzierz (w województwie kujawsko-pomorskim) za wodę płynącą, a części północnej za wodę stojącą. Jest to najbardziej skrajny przykład skutków nieprecyzyjnie sformułowanych przepisów prawa, które nie są dostosowane do praw obowiązujących w środowisku przyrodniczym.

\section{ZAKOŃCZENIE}

Z przedstawionej analizy wynika, że problem określenia typu jezior według Prawa wodnego staje się coraz bardziej skomplikowany $\mathrm{z}$ uwagi na występowanie szeregu powiązanych ze sobą i zależnych od siebie elementów środowiska. Należy zadać pytanie, $\mathrm{z}$ jakiego powodu przepisy ustawy Prawo wodne z 2001 roku nie nawiązują do ogólnie przyjętej w nauce klasyfikacji wód powierzchniowych? Przepisy te nie odpowiadają przedmiotowi swojej regulacji i w sposób nieuzasadniony skupiają się prawie wyłącznie na ocenie obecności (lub braku) dopływu i/lub odpływu z jeziora. Tymczasem dla wielu jezior dopływ i/lub odpływ powierzchniowy nie jest prawie w ogóle istotny. Tak samo lub nawet bardziej istotne mogą być płytkie wody podziemne zasilające lub/i przepływające przez jeziora. 
Płytkie wody podziemne mają kontakt z wodami powierzchniowymi płynącymi i stojącymi, mogą stanowić główne źródło zasilania jezior, a w ogóle są pomijane $\mathrm{w}$ ustawie. Nie oznacza to jednak, że powinny zostać w niej uwzględnione. Podany przykład ma na celu jedynie zwrócenie uwagi, że w ustawie wiele miejsca poświęca się jednym elementom, a całkowicie pomija inne, co najmniej tak samo istotne.

Biorąc pod uwagę wyżej opisane okoliczności i podane przykłady, zdaniem autorów, należałoby rozważyć możliwość rezygnacji z części skomplikowanych norm zawartych w Prawie wodnym z 2001 roku, usunąć dwuznaczne bądź sprzeczne ze sobą (a także ze środowiskiem naturalnym) przepisy, a w efekcie upodobnić istniejącą regulację do rozwiązań obowiązujących w innych krajach europejskich oraz we wspomnianej Ramowej Dyrektywie Wodnej.

\section{BIBLIOGRAFIA}

Bajkiewicz-Grabowska E., Mikulski Z., Hydrologia ogólna, Warszawa 2008.

Kubiak-Wójcicka K., Marszelewski M., Definitions and evolutions of the terms "flowing and stagnant waters" in the context of the proprietorship of the lakes in Poland, "Limnological Review" 2012, nr 4.

Mapa Podziału Hydrograficznego Polski, Warszawa, 2005.

Paczuski R., Opinia do projektu ustawy Prawo Wodne. Ekspertyza nr 52, Kancelaria Sejmu, Biuro Studiów i ekspertyz, Warszawa 1995.

Paczuski R., Potrzeby i problemy reformy polskiego prawa wodnego, [w:] M. Bączyk (red.), Księga pamiątkowa ku czci Profesora Leopolda Steckiego, Toruń 1997.

Rudnicki S., O własności wód, "Nowe Prawo" 1982, nr 7-8.

Szachułowicz J., Prawo wodne. Komentarz, Warszawa 2010.

Wierzbowski B., Rakoczy B., Prawo ochrony środowiska. Zagadnienia podstawowe, Warszawa 2012.

Kontakt e-mail:

marszelewski@gmail.com 